\title{
ECONOMICS OF PLANTING PITS UNDER SORGHUM AND PIGEON PEA IN SEMI-ARID AREAS OF EASTERN KENYA
}

\section{Rebecca Yegon ${ }^{1, *}$, Hezron Nyarindo Isaboke², Geoffrey Christoper Mrema ${ }^{3}$, Peter Mtakwa ${ }^{4}$}

\author{
${ }^{1}$ Department of Land and Water Management, School of Agriculture, University of Embu, Kenya \\ ${ }^{2}$ Department of Agricultural Economics and Extension, School of Agriculture, University of Embu, Kenya \\ ${ }^{3}$ Department of Engineering Sciences and Technology, College of Agriculture, Sokoine University of \\ Agriculture, Tanzania \\ ${ }^{4}$ Department of Soil and Geological Sciences, College of Agriculture, Sokoine University of Agriculture, \\ Tanzania \\ *Corresponding author: becayegon@gmail.com
}

\begin{abstract}
Rainwater harvesting (RWH) is promoted in arid and semi-arid areas for increased yields. Planting pits are RWH systems that are used for collecting rainwater and runoff. Recently, there has been increased interest in the economic and environmental benefits of agricultural technologies for sustainable development. To contribute to this knowledge, the economics of Chololo and Five by Nine planting pits and sorghum and pigeon pea mulch was investigated at two sites in semi-arid Eastern Kenya for four seasons. The experiments were in a randomized complete block design in three replicates. Returns of planting pits and mulch were calculated by evaluating the benefit-cost (B: C) ratios and net present values (NPV) while considering water as an economic good. Planting pits were profitable for sorghum and unprofitable for pigeon pea production. The outcome differed with sites and seasons depending on rainfall availability. Chololo pits earned US\$ 92 to US\$ 786 per hectare whereas Five by Nine pits earned US \$ 59 to US\$ 955 per hectare. Mulches were beneficial for sorghum and pigeon pea production at Nkarini and unprofitable at Machang'a with the yield differing with seasons depending on rainfall availability. This study recommends Five by Nine and Chololo pits for sorghum production at Nkarini where it was economically viable in three out of four seasons.
\end{abstract}

Keywords: Economics, Planting pits, Profits, Rainwater harvesting, Yield

http://dx.doi.org/10.21776/ub.agrise.2020.020.1.3

Received 29 July 2019

Accepted 15 November 2019

Available online 31 January 2020

\section{INTRODUCTION}

Rainwater harvesting involves inducing, collecting and storing runoff for productive use (Boers and Ben-Asher, 1982). Considering that RWH conserves water resources and is used in areas lacking irrigation water as noted by Li et al. (2000), RWH technologies need promotion for increased yields and ecological benefits. This can be achieved through economic and environmental analyses. As highlighted by Rockström et al. (2016) water management to alleviate droughts and dry spells is a key pillar in sustainable agricultural intensification.

Sorghum (Sorghum bicolor $(L)$ Moench) is the fifth leading cereal in the world estimated by FAO to yield $634 \mathrm{~kg} \mathrm{ha}^{-1}$ in 2016 in Kenya (FAOSTAT, 2018). It is adapted to semi-arid and subtropical Africa where most of the world sorghum is grown for food and feed. Traditionally it's a poor man's crop, however, recent interest in substitution of 
barley malt with sorghum, development of sorghumbased products and biofuels has increased its commercial potential in Kenya (MALF, 2015). Promotion together with economic evaluation would assist in enabling the 2 million farmers living in Kenyan arid and semi arid lands (ASALs) to benefit from this emerging economic opportunity.

Pigeon pea (Cajanus cajan (L) Millsp) is the sixth most important legume worldwide. It is grown on 276124 ha in Kenya which is the sixth world producer after India, Burma, Tanzania, Malawi and Uganda with an average yield of $1600 \mathrm{~kg} \mathrm{ha}^{-1}$ (FAOSTAT, 2018). Pigeon pea is a high yielding food legume that can produce 7000 to $14000 \mathrm{~kg} \mathrm{ha}^{-}$ ${ }^{1}$ straw and 1000 to $2000 \mathrm{~kg} \mathrm{ha}^{-1}$ grain (Valenzuela and Smith, 2002).

However, Mergeai et al. (2001) established that pigeon pea has not achieved its production potential in Kenya due to limited inputs use, poor management, use of traditional low yielding varieties and inadequate market linkages. Farmers in ASALs also continue growing high water demanding crops due to lack of state support (Rockström et al. 2016). This emphasizes the need for continued research to support the development of drought tolerant crops.

Planting pits and mulch are water management technologies promoted in sub-Saharan Africa ASALs. The Kenya Institute of Organic Farming popularized them in Eastern Kenya (Mati, 2006). Studies on the economics of soil and water conservation do not give a straightforward answer on whether the benefits of soil conservation outweigh the costs. Tenge et al. (2005) found the costs of grass strips, bench terraces and Fanya juu bunds in Tanzania exceeded the income in the first two years with profits earned in subsequent years. Kauffman et al. (2014) in a study evaluating 11 soil conservation measures on soil erosion and ecosystem services (food production, water availability and energy production) found that conserving soil improved the ecosystem services by $20 \%$ with B: C ratios of 7 .

According to Ayuke et al. (2012), the methods used in estimating benefits of soil conservation include analysis of variance (ANOVA), stochastic dominance analysis, matching methods and damage cost functions. ANOVA compares group means of estimated crop yields on plots with and without soil conservation measures. Stochastic dominance analysis assesses profits by comparing and ranking expected crop production net returns in the presence and absence of soil and water conservation. Matching evaluates treatments by comparing treatments in a non-randomised study. Damage cost functions calculate the monetary value of crop yield loss of based on soil erosion rates on plots without soil conservation.

The economics of RWH for crop production have been evaluated using different methods. The simplest method involves comparing yields with and without RWH under the same experimental conditions. Hatibu et al. (2006) used gross margin analyses to evaluate the economics of RWH in Tanzania. Gross margin analyses involve the calculation of the benefits and costs of RWH. The difference between the two determines whether one gets a profit or a loss. Gross margin analyses enable capturing the variation in market prices and the different RWH systems used. However, they assume zero opportunity costs for labor.

This, however, is not the case considering that labor is the biggest investment in RWH as explained by Kaboré and Reij (2004) and Slingerland, and Stork, (2000). Thus not calculating it may give inaccurate results (Smith et al. 2011). To counter this, Smith et al. (2011) used a quadratic function to estimate the costs and benefits of RWH for millet and sorghum in Burkina Faso. The quadratic function method, however, does not include the environmental benefits of RWH. In addition, Senkondo et al. (2004) note that analyzing benefits of RWH does not usually consider the time value of money, which is important since RWH, gives benefits over time.

Rainwater harvesting harvests water, increases yields but also conserves nutrients through deposited sediment as well as improving nutrient use efficiency by concentrating water and nutrients close to the plant roots (Kaboré and Reij, 2004). The method by Liang and Van Dijk (2011), improved this by using the B:C analysis to analyze RWH financially and economically. The economic analysis estimates the economic, environmental and social effects whereas the financial analysis involved financial benefits and costs. In the economic analysis, the criterion for economic feasibility was the ratio of benefits to costs with RWH considered economically feasible if the B:C ratio was $>1$.

The economic costs of RWH are the initial investment and the operation and maintenance costs. 
The environmental costs included risks associated with RWH such as depleting water for downstream users. The economic benefit includes increased agricultural production and planting off-season. The environmental benefits were given as water and energy saving and the social benefits as raising social awareness and improving employment. Further the method by Liang and Van Dijk (2011) includes the time value of money reflected in the discount rate which is the opportunity cost of capital as well as considering the economic and environmental costs and benefits.

In the current times agricultural technologies need to increase productivity using limited resources, since it is critical to not only consider yields produced but also the ecological and economic benefits of technologies (Rustamova 2016). This supports the need to couple technological innovations with economic evaluation. This study sought to contribute to this knowledge gap by establishing the economic benefits of planting pits for sorghum and pigeon pea production in two sites in semi-arid Eastern Kenya. This study had one specific objective. To determine the economic benefits of Chololo and Five by Nine pits for sorghum and pigeon pea production.

\section{RESEARCH METHODS}

The study was conducted in two experimental sites: a farmer's field in Nkarini village $028^{\prime} \mathrm{S}$ and $37^{\circ}$ 76' E, Tharaka-Nithi County and Machang'a Secondary school, $0^{\circ} 46^{\prime} \mathrm{S}$ and $37^{\circ} 39^{\prime} \mathrm{E}$, Embu County, Eastern Kenya. The experiment was done for four seasons:
1. SR2013: October 2013 to March 2014
2. LR2014: March 2014 to July 2014
3. SR2014: November 2014 to March 2015
4. LR2015: April 2015 to August 2015

\section{DESCRIPTION OF STUDY SITE}

\section{Climate}

The rainfall range in Machang'a according to Jaetzold et al. (2006) ranges from $200 \mathrm{~mm}$ to 260 $\mathrm{mm}$ in the short rains (SR) and from $280 \mathrm{~mm}$ to 340 $\mathrm{mm}$ in the long rains (LR). Jaetzold et al. (2006) also give the rainfall ranges in Nkarini as $250 \mathrm{~mm}$ to 450 $\mathrm{mm}$ in the SR and $250 \mathrm{~mm}$ to $350 \mathrm{~mm}$ in the LR. The altitude of Machang'a is $1100 \mathrm{~m}$ and that of Nkarini is $1220 \mathrm{~m}$ above sea level. Temperatures in Machang'a range from 21 to $23^{\circ} \mathrm{C}$ whereas those in Nkarini range from 21 to $24^{\circ} \mathrm{C}$.

\section{Soils and Topography}

The soils in Machang'a are sandy loam Plinthic Cambisols (Jaetzold et al., 2006) characterized by low weathering rate and an iron rich horizon that hardens when exposed to water. Nkarini soils are highly weathered clayey Rhodic Ferralsols (Jaetzold et al., 2006). Both study sites had a gently sloping topography with slopes of 3-4\%.

\section{Experimental Design and Layout}

The experiments were laid out in RCBD with three replicates. The planting pits were treatments: WRWH, Five by Nine pits and Chololo pits. Five by Nine pits are planting pits used in Eastern Kenya having dimensions of $60 \mathrm{~cm}$ long, $60 \mathrm{~cm}$ wide and $60 \mathrm{~cm}$ deep. They are spaced $60 \mathrm{~cm}$ within the row and $75 \mathrm{~cm}$ between rows as described by Mati (2006). They were constructed by excavating the top soil and separating it from the subsoil then mixing the topsoil with manure and returning the manuretopsoil mixture into the pit. One sorghum or pigeon pea seed was planted at each corner of the pit and one in the middle following (Mati, 2006).

Chololo pits are planting pits used in Dodoma, Central Tanzania dug as described by Mati (2006), having a diameter of $22 \mathrm{~cm}$, a depth of $30 \mathrm{~cm}$ spaced $60 \mathrm{~cm}$ apart within rows and $90 \mathrm{~cm}$ between rows with rows running along the contour. The topsoil, crop residues, and manure were mixed and returned to the pits and two sorghum seeds planted on the sides of each pit. Each plot was $10 \mathrm{~m}$ long and $3 \mathrm{~m}$ wide with a meter path between plots. Five by Nine pits were constructed in SR2013 and used in the subsequent three seasons without removing deposited sediment. Chololo pits filled with sediment after the first three rain events at the beginning of each season which was removed before planting in the subsequent season. The plots WRWH were plowed by hand hoe before planting in SR2013 and only planting holes made in subsequent seasons. Soil bunds were made around each plot to restrict runoff within each plot.

Gadam sorghum variety was planted at $75 \times 20$ $\mathrm{cm}$ spacing whereas KAT 60/8 pigeon pea variety was planted at $75 \times 50 \mathrm{~cm}$ WRWH; Five plants per Five by Nine pit and two plants per Chololo pit. Fertilizers were applied to provide optimal sorghum and pigeon pea nutrition both as inorganic fertilizers and manure in the SR with none added in the LR. The fields were maintained weed-free by weeding 
with a hand hoe whereas insects were controlled by spraying with Buldock insecticide. Sorghum was protected from bird damage by scaring and covering the panicles with brown paper from flowering to harvest.

\section{Measurements}

At physiological maturity in both experiments, plants in a net plot of $18 \mathrm{~m}^{2}$ were harvested, threshed to separate grains, winnowed, cleaned and weighed to determine grain yields using a portable electronic scale. The plants were cut at the base sun-dried for two weeks and weighed using a portable electronic scale to obtain straw yields. Dry matter yields were extrapolated to a hectare basis using plant populations corrected for the number of germinated plants per plot. All dry matter yields were expressed at $12.5 \%$ moisture content.

Detailed data on labor costs collected seasonally for each of the field operations (land preparation, pit construction, and maintenance, planting, fertilizer application, thinning, weeding, pest control and harvest). Labour was valued at the local wage of US\$ 3 per 8 hours at an exchange rate of 1 US\$ to KeS. 100. Benefit-Cost Analysis described by Liang and Van Dijk, (2011) was used to calculate the economic analysis of planting pits using equations (1) and (2) below:

$$
E_{c}=C_{1}+C_{O \& M}
$$

Where:

$\mathrm{E}_{\mathrm{c}}$ is the Economic cost

$\mathrm{C}_{1}$ the initial investment

$\mathrm{C}$ O\&M is the present value of operation and maintenance cost.

$C_{O \& M}=\sum_{t=1}^{m} x \frac{O_{t}}{(1+t)^{t}}$

Where $\mathrm{O}_{t}$ is the operation and maintenance cost in season $\mathrm{t}, \mathrm{i}$ is the discount rate which according to the Central Bank of Kenya (2016) was $18 \%$ in April $2016, \mathrm{~m}$ is the evaluation period. In the present study, there were no social risks associated with planting pits.

The economic benefit $\left(\mathrm{E}_{\mathrm{B}}\right)$ was calculated using equation (3) below:

$$
E_{B}=a_{m} \times S_{p}
$$

Where $\mathrm{a}_{\mathrm{m}}$ was the income from sorghum/pigeon pea (Ksh.) and $\mathrm{S}_{\mathrm{p}}$ the yield obtained $\left(\mathrm{kg} \mathrm{ha}^{-1}\right)$.
The environmental benefit considered in the present study was the water harvested for each entire season. Soil nutrient variations were not considered. The environmental benefit $\mathrm{E}_{\mathrm{w}}$ was calculated using equation (4) as:

$$
E_{W}=V_{W H}+C_{W}
$$

Where $\mathrm{V}_{\mathrm{wH}}$ was the total volume of water harvested per season in each treatment $\left(\mathrm{m}^{3}\right), \mathrm{C}_{\mathrm{w}}$ the cost of water of US\$ $0.40\left(75 \%\right.$ of US\$ $\left.0.53 \mathrm{~m}^{-3}\right)$ charged for water by the Embu Water and Sewerage Company considering water as an economic good.

In the study by Liang and Van Dijk (2011), awareness creation on the use of RWH and employment creation were calculated as social benefits. Since these were not applicable in the present study, whereby unlike in the Liang and Van Dijk (2011) study where there was community sensitization on the benefit of RWH with some people employed on the farms, the present study was an experimental study and not community-based thus these benefits were not calculated.

After quantifying the economic and social costs and the environmental and economic benefits, calculations of the present value of costs $\mathrm{EC}_{\mathrm{pv}}$ and the present value of benefits $\mathrm{EB}_{\mathrm{pv}}$ using equations (5) and (6) was as follows:

$$
\begin{aligned}
E C_{p v}= & \sum_{t=1}^{m} E A \div(1+i)^{t}+\mathrm{E}_{\mathrm{c}} \ldots \ldots \ldots \ldots \ldots \ldots \\
E B_{p v}= & \sum_{t=1}^{m} E_{p} \div(1+i)^{t}+\sum_{t=1}^{m} E_{B} \div(1+ \\
& i)^{t}+\sum_{t=1}^{m} E_{a w} \div(1+i)^{t} \ldots \ldots \ldots \ldots \ldots
\end{aligned}
$$

The B: C ratio is the criteria for economic feasibility with a value $>1$ indicating economic feasibility. The ratio was calculated using equation (7) as:

$$
\operatorname{Er} 1_{\frac{b}{c}}=E B_{p v} \div E C_{p v}
$$

The NPV of planting pits and mulch were calculated using equation (8) as:

$$
N P V=E B_{p v}-E C_{p v}
$$

\section{Data analysis}

All yield data was analyzed for normality before subjection to analysis of variance (ANOVA) using GENSTAT version 14 (GENSTAT Committee, 2011). The pits and mulch levels were the treatments in the analysis of grain and biomass yield. The analysis for each site, crop and season conducted 
independently. Plant population treated as a covariant. Means separated using Tukey's honest significant test at a $\mathrm{P} \leq 0.05$. Statistical Package for Social Sciences (SPSS) used to calculate the economic benefits of planting pits and mulch.

\section{RESULTS AND DISCUSSION}

\section{Economics of PLANTING PITS FOR sorghum production}

Sorghum production without rainwater harvesting (WRWH) was uneconomical at Machang'a in SR2014 and SR2013 with B: C ratios of 0.20, 0.54, respectively. Without rainwater harvesting turned out to be important in LR2015 and LR2014 seasons with ratios of 1.10 and 1.74 (Figure 1). This earned US\$ 55 and US\$ 118 profits per hectare respectively (Figure 1). Sorghum production in Five by Nine pits was low at this site in SR2013, LR2014 and LR2015 seasons with B:C ratios of 0.04, 0.31 and 0.94 respectively, and high in LR2014 with a B:C ratio of 1.37. This earned a profit of US\$ 59 per hectare (Figure 1). At this site, sorghum production in Chololo pits had a similar trend to the Five by Nine pits being of minimal value in the SR2013, SR2014 and LR2015 seasons having B: C ratios of 0.08, 0.19 and 0.33. Chololo pits were on the other hand beneficial for sorghum production in LR2014 at Machang'a having a B: $\mathrm{C}$ ratio of 1.30 with a profit of US\$ 92 per hectare (Figure 1).

At Machang'a, RWH had a good effect once in three seasons and WRWH in two out of four seasons. This finding differs with Amede et al. (2011) who found planting pits profitable in bean and potato production in Ethiopia. This may have been contributed by the higher costs incurred in this site that was in an area with higher labor costs especially in excavating the planting pits due to the sandy loam soils which had a Plinthic (hard murram) horizon that resulted in the cost of the planting pits doubling compared to the costs in Nkarini. The cost of manure was also double since it was from outside the locality whereas that at Nkarini it was from the host farmer hence a cheaper price. In addition, birds were not a major problem at Nkarini in the SR when most farmers planted sorghum but at Machang'a, few farmers planted sorghum thus making birds to be a major sorghum pest hence necessitating bird scaring that further increased costs.

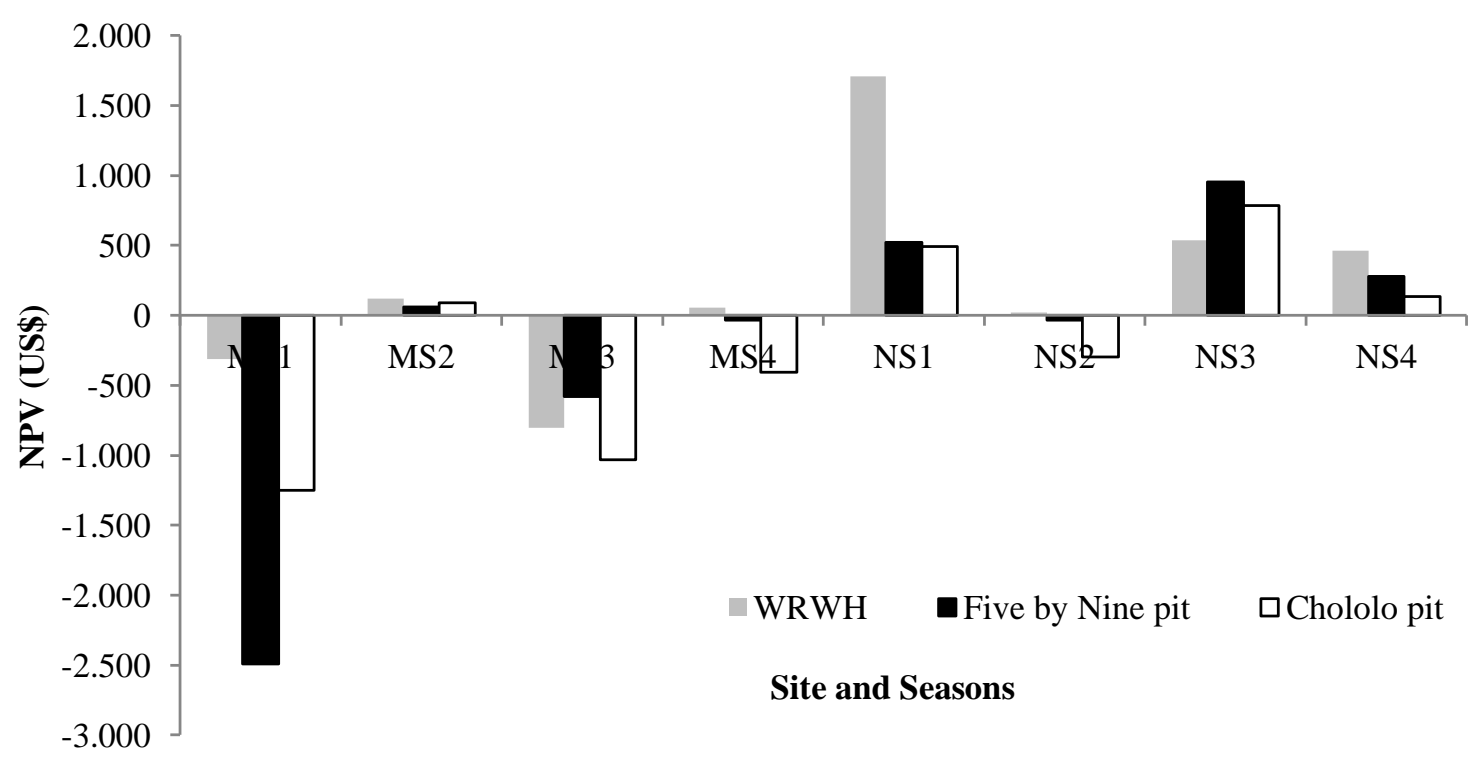

Figure 1. Four seasons sorghum NPV at Machang'a (M) and Nkarini (N), Kenya; S1: SR2013; S2: LR2014; S3: SR2014; S4: LR2015

The B: C ratios of 1.30 and 1.37 obtained at Machang'a during season two are comparable to the 1.1-1.5 found by Senkondo et al. (2004) in Tanzania. Considering that WRWH was more profitable than planting pits implies that in the short term, planting pits may be unattractive to farmers in Machang'a as noted by Hatibu et al. (2006). However, this was mainly due to the cost of constructing the planting 
pits, which can be cheaper in the longer term. This is especially for Five by Nine pits, which were suitable for an additional four seasons without maintenance at Machang'a.

Growing sorghum WRWH gave value for money in Nkarini in all four seasons, having a B:C ratio of 6.16, 3.62, 3.06 and 1.10 in SR2013, SR2014, LR2015 and LR2014 seasons, respectively. This resulted in profits of US\$20, US\$ 464, US\$ 537 and US\$ 1707 per hectare, respectively (Figure 1). In this site, growing sorghum in Five by Nine pits had a dismal performance in LR2014 and an economically sensible one in the SR2013, LR2015 and LR2014 seasons with B:C ratios of $0.83,1.80,2.59$ and 4.66 , respectively. The profits earned were US\$281, US\$ 520 and US\$ 955 per hectare, respectively as shown in Figure 1. Growing sorghum in Chololo pits in this site had a similar tendency to Five by Nine pits being uneconomical in LR2014 with a B: C ratio of 0.43 and with better returns in LR2015, SR2013 and LR2014 seasons with ratios of 1.53, 1.87 and 3.18 respectively. This earned profits of US $\$ 135$, US\$ 493 and US\$ 786 per hectare as indicated in Figure 1.

At Nkarini WRWH was favourable for sorghum production in all four seasons whereas both planting pits were productive in three out of four seasons. This finding is similar to those by Senkondo et al. (2004) who showed that investment in RWH for crop production is ultimately profitable for farmers who can pay for the investment and operational costs. The B:C ratios of 1.18 and 1.89 obtained in this study for sorghum in both planting pits at Nkarini in season one are similar to the 1.1-1.5 found by Senkondo et al. (2004) and 1.6 found by Liang and Van Dijk, (2011) for small RWH systems. However, the 2.67-4.7 found at Nkarini are twice those of Senkondo et al. (2004) and Liang and Van Dijk, (2011) highlighting the high profits obtained in Nkarini. Considering that WRWH was more profitable than planting pits implies that in the short term, planting pits may tend to be unattractive to farmers (Hatibu et al., 2006). This was mainly due to the longer term benefis of planting pits.

\section{Economics of planting pits for pigeon pea production}

Growing pigeon pea WRWH and in Chololo and Five by Nine pits was largely unattractive having $\mathrm{B}: \mathrm{C}$ ratios of 0.09 to 0.96 in all four seasons in both sites with the exception of Five by Nine pits which were meaningful in LR2014 at Nkarini at a ratio of 1.57 earning US\$ 169 profit (Table 1). This study found Five by Nine pits to be gainful for pigeon pea production in one out of four seasons at Nkarini and financially not rewarding in all four seasons at Machang'a (Table 1).

This differs from the findings for sorghum in the present study and those of Amede et al. (2011) who found planting pits profitable for bean and potato production. This may be due to the low pigeon pea yields of $54 \mathrm{~kg} \mathrm{ha}^{-1}$ to $777 \mathrm{~kg} \mathrm{ha}^{-1}$ obtained in the present study compared to the average $16000 \mathrm{~kg} \mathrm{ha}^{-}$ ${ }^{1}$ potential yield in Kenya likely as a result of the low rainfall received in the present study. The $\mathrm{B}: \mathrm{C}$ ratios of 1.59 obtained in this study for pigeon pea in Five by Nine pits in Nkarini are akin to the 1.1-1.5 found by Senkondo et al. (2004) and 1.6 found by Liang and Van Dijk (2011) for small RWH systems.

The higher planting pits maintenance costs in the clay soils in this study differ with the findings of Kaboré and Reij (2004), who proposed that maintaining pits in clay soils was easier than maintaining pits in sandier soils. In this study, the Five by Nine pits in the clayey Nkarini soils gradually filled with sediment in each season and were $3 / 4$ full by the end of the four seasons. However, Five by Nine pits in the Machang'a sandy loams were still intact after the four seasons. This means that at Machang'a, Five by Nine pits were useful for more seasons without maintenance. However, as earlier noted in this study, the cost of establishing the planting pits in the sandy loam Cambisols in Machang'a, which had a Plinthic (hard murram) layer, was twice that in the clayey Ferralsols in Nkarini. The fluctuations in the returns of RWH observed in this study are consistent with the findings of Kaboré and Reij (2004) that profitability of planting pits differs with seasons in response to rainfall variability. 
Table 1. Economics of Four seasons of Planting Pits for Pigeon pea production

\begin{tabular}{|c|c|c|c|c|c|c|c|c|}
\hline \multirow{3}{*}{ RWH System } & \multicolumn{8}{|c|}{ Machang'a } \\
\hline & \multicolumn{2}{|c|}{ SR2013 } & \multicolumn{2}{|c|}{ LR2014 } & \multicolumn{2}{|c|}{ SR2014 } & \multicolumn{2}{|c|}{ LR2015 } \\
\hline & $\begin{array}{c}\text { NPV } \\
\left(\mathrm{US} \$ \mathrm{ha}^{-1}\right)\end{array}$ & $\begin{array}{l}\mathrm{B}: \mathrm{C} \\
\text { ratio }\end{array}$ & $\begin{array}{c}\text { NPV } \\
(\text { US\$ ha-1) }\end{array}$ & $\begin{array}{l}\mathrm{B}: \mathrm{C} \\
\text { ratio }\end{array}$ & $\begin{array}{c}\text { NPV } \\
(\text { US \$ ha-1) }\end{array}$ & $\begin{array}{l}\mathrm{B}: \mathrm{C} \\
\text { ratio }\end{array}$ & 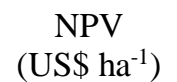 & $\begin{array}{l}\mathrm{B}: \mathrm{C} \\
\text { ratio }\end{array}$ \\
\hline Chololo pit & -1640 & 0.11 & -156 & 0.65 & $\begin{array}{l}-474 \\
\end{array}$ & 0.40 & -201 & 0.72 \\
\hline Five by Nine Pit & -2821 & 0.08 & -76 & 0.82 & -299 & 0.54 & -41 & 0.94 \\
\hline WRWH & 982 & 0.15 & -321 & 0.23 & -548 & 0.26 & -322 & 0.51 \\
\hline \multicolumn{9}{|c|}{ Nkarini } \\
\hline Cholo & -589 & 0.52 & -345 & 0.45 & -90 & 0.81 & -341 & 0.47 \\
\hline Five by Nine Pit & -568 & 0.62 & 169 & 1.57 & -50 & 0.87 & -95 & 0.77 \\
\hline WRWH & -265 & 0.58 & -135 & 0.54 & -194 & 0.49 & -213 & 0.48 \\
\hline
\end{tabular}

\section{CONCLUSION}

This study sought to establish the efficacy of planting pits for sorghum and pigeon pea production. It concludes that planting pits are suitable for sorghum and pigeon pea production in semi-arid areas of Eastern Kenya. The benefits, however, differs with sites and seasons being dependent on rainfall availability.

The study, therefore, recommends Five by Nine and Chololo pits for sorghum production at Nkarini where the pits yielded substancial returns in three out of four seasons. Although the Five by Nine pits are recommended because of their potential for increasing sorghum production, there is no very strong evidence of it's effectiveness in pigeon pea production being that only one season turned out to be profitable. In addition, the Chololo and Five by Nine pits are unsuitable for Machang'a because they were profitable in one in out of the four seasons having B: C ratios of 1.36 and 1.46 .

Further studies are required under farmers' conditions at Machang'a to validate this finding and for a longer period considering the fact that, the Five by Nine pits after the four-season study was still suitable for an additional four seasons without maintenance. Reducing the costs of the planting pits for example, by government subsidizing the costs of constructing the pits as they have been doing for sorghum and pigeon pea seeds under the traditional high value crops in the state department of Agriculture in Kenya may further promote the technology. Further studies on enhanced farmmarket linkages and their implications in growing sorghum, and promotion of planting pits are recommended.

\section{ACKNOWLEDGEMENTS}

The authors thank the Alliance for Green Revolution in Africa (AGRA) for funding this study, Mr. David Muthengi in Nkarini village for allowing us to use his farm, Mr. Kithome for his hospitality and Mr. Kiragu and Mr. Kithaka for assistance with the field activities.

\section{REFERENCES}

Amede, T., Menza, M. and Awlachew, S. B. (2011). Zaï improves nutrient and water productivity in the Ethiopian highlands. Experimental Agriculture 47(1): 7-20. http://doi.org/10.1017/S0014479710000803

Ayuke, F. O., Karanja, N. K., Okello, J. J., Wachira, P. M., Mutua, G. K., Lelei, D. K. and Harrison, R. (2012). Agrobiodiversity and potential use for enhancing soil health in Tropical soils of Africa. Soils Food Security 35: 94-134.

Boers, T. M. and Ben-Asher, J. (1982). A review of rainwater harvesting. Agricultural Water Management 5(2): 145-158. http://doi.org/10.1016/0378-3774 (82)90003-8

FAOSTAT, FAO. (2018). Food and Agriculture Organization of the United Nations Statistics Division (2016). Production. [http://faostat3.fao.org/browse/Q/QC/S] site visited on $10^{\text {th }}$ December 2018.

GENSTAT 14 Committee. (2011). GenStat for Windows. VSN International Limited.

Hatibu, N., Mutabazi, K., Senkondo, E. M. and Msangi, A. S. K. (2006). Economics of Rainwater Harvesting for Crop Enterprises in Semi-Arid Areas of East Africa. Agricultural Water Management 80(1-3). pp 74-86. http://doi.org/10.1016/ j.agwat.2005.07.005. 
Jaetzold, R., Schmidt, H. and Shisanya, C. (2006). Farm Management Handbook of Kenya Natural Conditions and Farm Information, Sub Part Cl, Eastern Kenya ( $2^{\text {nd }}$ ed. Vol. 2). Nairobi: Ministry of Agriculture. pp 67-78.

Kaboré, D. and Reij, C. (2004). The Emergence and Spreading of an Improved Traditional Soil and Water Conservation Practice in Burkina Faso. EPTD Discussion Paper No. 114.

Kauffman, S., Droogers, P., Hunink, J., Mwaniki, B., Muchena, F., Gicheru, P., Bindraban, P., Onduru, D. and Bouma, J. (2014). Green Water Credits-exploring its potential to enhance ecosystem services by reducing soil erosion in the Upper Tana basin, Kenya. International Journal of Biodiversity Science, Ecosystem Services and Management 10(2): 133-143.

Liang, X. and Van Dijk, M. P. (2011). Economic and Financial Analysis on Rainwater Harvesting for Agricultural Irrigation in the Rural Areas of Beijing. Resources, Conservation and Recycling 55(11): 1100-1108.

http://doi.org/10.1016/j.resconrec.2011.06.009

Li, F., Cook, S., Geballe, G. T. and Burch Jr, W. R. (2000). Rainwater Harvesting Agriculture: An Integrated System for Water Management on Rainfed Land in China's Semiarid Areas. AMBIO: A Journal of the Human Environment 29(8): 477-483.

Mati, B. M. (2006). Overview of Water and Soil Nutrient Management under Smallholder Rainfed Agriculture in East Africa (Vol. 105). Colombo: IWMI. pp 28-30.

Mergeai, G., Kimani, P., Mwang'ombe, A., Olubayo, F., Smith, C., Audi, P. and Le Roi, A. (2001). Survey of Pigeon Pea Production Systems, Utilization, and Marketing in SemiArid Lands of Kenya. Biotechnologie, Agronomie, Société et Environnement 5(3): 145-153.
Ministry of Agriculture Livestock and Fisheries (MALF). (2015). Economic Review of Agriculture [ERA] 2015. Nairobi. Government Printer. pp 14-16.

Rockström, J., Williams, J., Daily, G., Noble, A., Matthews, N., Gordon, L. and Smith, J. (2016). Sustainable Intensification of Agriculture for Human Prosperity and Global Sustainability. Ambio 1:1-14. http://doi.org/10.1007/s13280016-0793-6

Rustamova, I. B. (2016). Evaluation of Economic Efficiency of Using Resource Saving Technologies (Conservation Agriculture) in Irrigated Lands. Journal of Global Economics 4(2): 1-5. http://doi.org/10.4172/23754389.1000197

Senkondo, E. M., Msangi, A. S. and Hatibu, N. (2004). Profitability of Rainwater Harvesting for Agricultural Production in Selected SemiArid Areas of Tanzania. Journal of Applied Irrigation Science 39(1): 65-81.

Slingerland, M. A., and Stork, V. E. (2000). Determinants of the Practice of Zaï and Mulching in North Burkina Faso. Journal of Sustainable Agriculture 16:53-76. http://doi.org/10.1300/J064v16n02.

Smith, R. B. W., Hildreth, L. A. and Savadago, K. (2011). Evaluating the Economic Impacts of Water Harvesting in Burkina Faso. UNEP. Working paper 6. Nairobi. pp 1-14.

Tenge, A. J. and Hella, J. P. (2005). Financial efficiency of major soil and water conservation measures in West Usambara highlands, Tanzania. Applied Geography 25(4): 348-366.

Valenzuela, H. and Smith, J. (2002). Pigeon Pea. Cooperative Extension Service, College of Tropical Agriculture and Human Resources. pp 5-6. www.centralbank.go.ke. Central Bank of Kenya Lending rate. (2016). Accessed on $15^{\text {th }}$ August 2016. 